\title{
Partial least squares structural equation modeling in online shopping: The moderator effect between impulsive buying tendency and behavior CHANG CHE-CHANG ${ }^{1}$; HUNG YING-YUN ${ }^{2}$; WANG YI-CHOU ${ }^{3 *}$ \\ ${ }^{1}$ Huashang College Guangdong University of Finance and Economic, Guangdong, CHINA \\ 2.3..Department of International Business Management, Tainan University of Technology, Tainan, TAIWAN
}

\begin{abstract}
Single's Daywas first promoted by Alibaba's shopping website on November 11, 2009. Ten years later, Taobao successfully developed this day into a global carnival shopping festival. This research focuses on undergraduate business school students through online questionnaires across the Taiwan Strait. This study is based on five impact factors, including impulse buying tendencies, herd behavior, website features, promotional techniques and impulse buying behavior. No evidence showed that gender, age and monthly disposable income affect students' buying behavior. This study also found that herd behavior, website features and promotional techniques are moderator effects between impulse buying tendency and impulse buying behavior. We also proved that website design and the opinions of their peers affect consumers' decision aking. According to the analysis, in the current online shopping environment, operators should pay more attention to herd behavior, website features and promotional techniques. This study suggests that the industry should provide sufficient information to reduce emotional conflict, and use these important factors to attract consumers' future purchases.
\end{abstract}

Keywords: Double 11, Online Shopping, Herd Behavior, Website Features, Promotional Techniques.

Received: November 12, 2019. Revised: May 26, 2020. Accepted: May 29, 2020. Published: June 4, 2020.

\section{Introduction}

Single's Day, also called Double Eleven (11/11), is an unofficial shopping holiday in China. It originated with the Taobao Mall promotion by Alibaba's shopping website on November 11, 2009. It was designed to engage consumers in online shopping by means of promotional activities. The first event, a shopping festival, was a great success. Even the project manager of T-mall could not imagine that 27 brands of discounted products could bring in 50 million RMB in a day. By 2019, the final turnover of the ninth (11/11) shopping festival was \$ 38.1 billion. Compared with 2018, the turnover rate grew by $25.7 \%$ [38]. Nowadays, the 11/11 Shopping Festival has become a global shopping carinal festival, with all the countries in the world getting involved.

Earnings reflect business operation and their strategies performances[19].In order to take advantage of the 11/11 Shopping Festival, many online shopping platforms have conducted various promotional activities to encourage consumers to ship via the internet. Nowadays, online shopping has become a phenomenon of modern society. The shopping festival is a battlefield of shopaholics and store owners. It is a big issue to understand how to move from buying tendencies to actual buying behavior. This study explores consumers' online shopping behaviors by considering the impacts of various factors, including impulsive buying tendencies, herd behavior, website features and promotional techniques, on buying behavior. We also try to explain their relationships.

\section{Problem Formulation}

Research on the effects of personality traits on impulsive buying behaviour is widely available [2].[44] suggested that impulse buying behaviour is related to consumers' lack of control of cognitive attitudes, including the cognitive component, affective component and behavioural component, when impulse buying[7]. [1] proved that subjective norms obviously impact intentions to purchase travel products online. Four kinds of characteristics have been considered as impulse purchase behaviour, including emotional conflict, positive purchase attitude, prudence and disregard [33]. Emotional conflict refers to the budget constraints on buying behaviour. Whether or not a person can enjoy his or her life by buying as much as one desires in real time, control of the impulse to purchase is characterized by internal conflicts, struggles and imbalances. Positive purchase attitude refers to the consumers' positive attitude when buying items. Prudence refers to careful and cautious attitudes before buying items. Disregard for 
the future refers to consumers' sudden and spontaneous purchase desires without considering the consequences. [41] pointed out that consumers' perceived enjoyment and impulse buying tendencies greatly affect their impulse purchases, while providing meaning and limitations, and stimulating discussion. If consumers are unable to control their desires, they might purchase items beyond their budget or purchase impractical items 4 .

Herd behaviour leads to similar strategies or outcomes [22]. Herding may be either intentional or unintentional 8. Based on the results of previous studies on herd behaviours, such behaviours are shaped by information impact and regulation impact [24]. Regulation impact means that when an individual recognizes the convention of the group, he/she will change himself/herself, and decide to adopt the same actions and behaviours as the group. Information impact in this study is defined as the consumers' sudden and spontaneous purchase desires which arise without considering the consequences. Consumers are unable to control their desires, but purchase items beyond their budget, or purchase items that are impractical [42].

Shopping behaviour at retail stores has been changed because of online shopping. Experiences for online shopping are still highly contextual and important [5]. Therefore, website features influence the store products on display. Website managers have strong interest in the entire value of a transaction, because their profits are associated with shipping costs [3]. [17] showed that irritating website designs have negative effects on all aspects of consumer buying behaviour. For [29], the key factors are what product is being shopped for, website features and where shopped takes place [3]\&[16]. [32]classified website features into three categories, design, content and security and privacy. Website design means the website should have a user friendly interface for users to access information. Website content provides users with the latest information about items. Website security and privacy determines how a website protects consumers' privacy and personal information[20]

$[10]$ studied the classification of promotional activities. [46]pointed out that promotional activities of online shops differ from promotional activities in traditional shops. The previous study classified promotional techniques as price-oriented or nonprice-oriented in promoting online products [9]\& [12]. [30] showed that incentives provided to dealers or consumers have significant effects their buying behaviour. [36] study also demonstrated that rewards can encourage consumers to actively purchase promote products [25]. Price-oriented activities refer to monetary forms by directly reducing the price of products by means of coupons or discounts. Non-price-oriented activities involve increasing the additional value of products by means of lottery and gifts, which has nothing to do with the price of products. Additionally, shops often allow consumers to enter lottery drawings to gain some advantages or send small gifts as rewards to consumers. These additional gifts accompanying purchased items make consumers feel they gained something extra.

[37] defined an impulse buying behaviour as an unplanned purchase and found impulse buying is mostly induced by cheap items. The above theory offered a new perspective on consumers' buying theories. However, Stern's definition is not comprehensive enough and has led to follow-up discussions. Many scholars argue that consumers often make reasonable and good plans for their buying decisions[41]. [39]proposed that impulse shopping occurs when consumers are eager to purchase a specific product without carefully considering the reasons for the purchase[45]. Emotions and ease of use lead to the desire for impulse shopping. [27] showed that low impulse consumers tend to spend less money on technical products. In other contexts, no significant differences in buying decisions have been shown between high and low price impulse consumers. Therefore, this study classified impulse purchases into unplanned and planned purchases. An unreasonable impulse purchase means that the consumer sees an attractive commodity that they do no need, but he/she buys it immediately. A reasonable impulse purchase takes place when a consumer sees a promotion activity and is thus motivated to buy an item he/she needs.

\section{Methodology}

This research targets on doubt 11 consumers and try to figure out whether their consumer would be affect on follow factors. This is bases on the following two concepts: First, this study would be divided into two types of impulsive purchase consumers: the first is that there is no plan in mind, and the purchase behavior will be entirely due to their own impulsive purchase characteristics, herd behavior and the influence of website characteristics. The second is that it has long been planned, but it is just waiting for a promotional event or price discount before buying. Merchants can use the above two mentality to propose more attractive activities to consumers to attract consumers to buy and earn more benefits. Second, with the maturity of consumers and online shopping 
environments, businesses should pay more attention to website design, price promotion, and information influence and planned purchases. The operator can distinguish his customers by their high or low impulsive qualities: the first one: those with high impulsive qualities are unplanned purchases, using website features, herds, promotion methods, which are invalid for this type, must Think of other ways to cope. The second kind: low impulsive characteristics, price promotion is a very effective way to cope. Businesses can use the above two mentalities to propose more attractive activities to consumers to attract consumers to buy and earn more benefitsA large portion of online shopping is attributed to impulse purchases. [21] argued that herd behaviour has a greater impact on impulse buying tendencies. Therefore, this study proposes Hypothesis 1. [40] stated that online consumers are both impulse shoppers and system users of the website during the purchase process. Therefore, this study proposes Hypothesis 2. [18]pointed out that marketing incentives for addictive products can trigger impulse purchases by delivering consumer reminders. [26]showed that if consumers feel less time pressure or have more funds available, it will positively affect impulse buying propensities. Therefore, this study proposes Hypothesis 3. [43] stated that the trust in a website, auction initiator and buyer are prerequisites for attitudes towards online group buying behaviours. Group behaviour may be based on word-of-mouth effect. Electronic word-of-mouth information is an important factor affecting the persuasion effect [28].[31]therefore, this study proposes Hypothesis 4. [4] studied a group buying website and found that the number of participating customers gives a positive boost to online shopping decisions. Therefore, this study proposes Hypothesis 5. [25] has found that customers use social networking sites to help make purchasing decisions and assist online vendors in developing advertising and promotion strategies. Therefore, this study proposes Hypothesis 6. [23] argued that the privacy provided by websites allows consumers to search for and purchase products. When customers do not need to think about embarrassing situations, the number of unplanned products purchased increases significantly. Therefore, this study proposes Hypothesis 7.[28]mention that herb behavior will affect buying websites. Therefore, thisstudy proposes Hypothesis 8 \& 9.Based on previous research, this study proposes a research framework, as shown in Figure 1. These core hypotheses will be tested using PLS-SEM software.

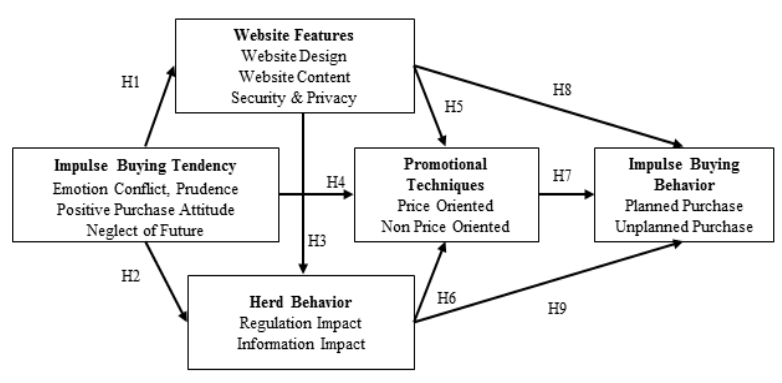

Figure 1. Theoretical framework

H1: Impulse buying tendency has a positive impact on herd behaviour.

H2: Impulse buying tendency has a positive impact on website features.

H3: Impulse buying tendency has a positive impact on promotion techniques.

H4: Herd behaviour has a positive impact on website features.

H5: Herd behaviour has a positive impact on promotion techniques.

H6: Website features have a positive impact on promotion techniques.

H7: Promotion techniques have a positive impact on impulse buying behaviour.

H8: Herd behaviour have a positive impact on impulse buying behaviour.

H9: Website features have a positive impact on impulse buying behaviour.

This study adopted questionnaires to explore the factors affecting consumers' impulse buying behaviors. The questionnaires were issued to students of management colleges across the Taiwan Strait. According to [14], studies attempting to predict key target constructs or identify key driver constructs should select PLS-SEM. Therefore, this study uses SmartPLS 3.0 as a data analysis tool. The sample size is part of the overall study. It is considered to be an important factor to reducing sampling errors. According to some statistical experts, the data range should be 5 to 10 times the number of items used in the scale [15]. Therefore, it is recommended that the samples size should be 10 times the number of research questions. This research has 30 questions, so a valid sample should exceed 300 .

\section{Data analysis}

Characters'statistics of the sample: This study collected 205 questionnaires in China and 170 in Taiwan. In total, 364 were valid questionnaires were collected after deducting 11 invalid questionnaires (missing data). Most of them are between 18 to 24 years old. The sample consisted of 375 adult (180 females and 184 males). A total of $180(49.5 \%)$ 
females and $184(50.5 \%)$ males. In this study, using chi-square test to explore data of different genders. The Chi-square test of independence (Pearson Chisquare test or $\chi 2$ ) is useful statistics for testing that are there significant differences in the sample variables.

There was no significant difference, $\chi 2=$ $4.568, \mathrm{p}=.335$, between genders and careers. There was no significant difference, $\chi 2=4.591, \mathrm{p}=.468$, between genders and ages. There was no significant difference, $\chi 2=9.002, \mathrm{p}=.062$, between genders and disposable Income.There was no significant difference, $\chi 2=6.715, \mathrm{p}=.172$, between gender and education degree. Therefore, there is no significant difference in gender between samples. There was significant difference, $\chi 2=65.252, \mathrm{P}$ $=.000$, between ages and disposable Income. There was significant difference, $\chi 2=33.074, p=.000$, between ages and education degree. There was significant difference, $\chi 2=116.700, \mathrm{p}=.000$, between ages and occupations. Therefore, ages have significant difference in samples. Certainly, occupations and disposable income have significant impact $\chi 2=85.179, \mathrm{p}=.000$. There was also significant difference, $\chi 2=22.615, \mathrm{P}=.040$, between education degrees and occupations.The higher the education level obtain better occupations, and the better occupations have higher the disposable income.

This study also use item-analysis to identify the degree of response of different for each questionnaire. All questionnaire critical value of each item reaches a significant level. The content of the questionnaire is coded into Table 1 . There are five research constructs are divided into A, B, C, D and $\mathrm{E}$ by following table1. Every questionnaire factor loading has more than 0.5 .

Table 1: Questionnaires for Code and Loading ImpulseBuying Tendency

\begin{tabular}{|l|l|l|}
\hline Code & Loading & Items \\
\hline A1 & 0.682 & $\begin{array}{l}\text { I have no habit of planning use } \\
\text { a purchase list. }\end{array}$ \\
\hline A2 & 0.769 & $\begin{array}{l}\text { Impulse purchases make me } \\
\text { feel exhilarated. }\end{array}$ \\
\hline A3 & 0.500 & $\begin{array}{l}\text { I only consider the most } \\
\text { suitable and appropriate items. }\end{array}$ \\
\hline A4 & 0.846 & $\begin{array}{l}\text { I consider all possible } \\
\text { situations carefully. }\end{array}$ \\
\hline A5 & 0.820 & $\begin{array}{l}\text { I will consider all possible } \\
\text { situations. }\end{array}$ \\
\hline Herd Behavior \\
\hline Code & Loading & Items \\
\hline B1 & 0.877 & $\begin{array}{l}\text { It is important the surrounding } \\
\text { people like the items I buy. }\end{array}$ \\
\hline
\end{tabular}

\begin{tabular}{|l|l|l|}
\hline B2 & 0.875 & $\begin{array}{l}\text { I people dislike something, I } \\
\text { will not buy it. }\end{array}$ \\
\hline B3 & 0.903 & $\begin{array}{l}\text { If the items I buy are accepted } \\
\text { by society, I have a sense of } \\
\text { belonging. }\end{array}$ \\
\hline B4 & 0.887 & $\begin{array}{l}\text { Purchasing widely accepted } \\
\text { items gives me have a sense of } \\
\text { belonging and recognition. }\end{array}$ \\
\hline B5 & 0.919 & $\begin{array}{l}\text { I will consult others before } \\
\text { buying an unfamiliar } \\
\text { commodity. }\end{array}$ \\
\hline B6 & 0.819 & $\begin{array}{l}\text { I usually discuss with others } \\
\text { whether to ensure the items in } \\
\text { my purchase list are socially } \\
\text { acceptable. }\end{array}$ \\
\hline
\end{tabular}

Website Features

\begin{tabular}{|l|l|l|}
\hline Code & Loading & Items \\
\hline C1 & 0.808 & $\begin{array}{l}\text { Website should have a user } \\
\text { friendly interface. }\end{array}$ \\
\hline C2 & 0.764 & $\begin{array}{l}\text { Consumers privacy will be } \\
\text { protected by online shops. }\end{array}$ \\
\hline C3 & 0.822 & $\begin{array}{l}\text { The transaction method in } \\
\text { online shops are reliable. }\end{array}$ \\
\hline C4 & 0.798 & $\begin{array}{l}\text { Website should provide the } \\
\text { latest information about } \\
\text { products. }\end{array}$ \\
\hline C5 & 0.774 & $\begin{array}{l}\text { I think online shops have good } \\
\text { reputation. }\end{array}$ \\
\hline C6 & 0.793 & $\begin{array}{l}\text { Websites provide correct } \\
\text { information about the } \\
\text { products. }\end{array}$ \\
\hline C7 & 0.842 & $\begin{array}{l}\text { The websites allow consumers } \\
\text { to return or exchange items. }\end{array}$ \\
\hline Prom
\end{tabular}

Promotional Methods

\begin{tabular}{|l|l|l|}
\hline Code & Loading & Items \\
\hline D1 & 0.904 & $\begin{array}{l}\text { When I go online shopping, } \\
\text { discounts attract me. }\end{array}$ \\
\hline D2 & 0.920 & $\begin{array}{l}\text { The promotional activity } \\
\text { increases my willingness to } \\
\text { purchase. }\end{array}$ \\
\hline D3 & 0.856 & $\begin{array}{l}\text { Free gifts accompanying the } \\
\text { items will increase my } \\
\text { willingness to purchase. }\end{array}$ \\
\hline D4 & 0.878 & $\begin{array}{l}\text { Free transportation increases } \\
\text { my willingness to purchase. }\end{array}$ \\
\hline D5 & 0.857 & $\begin{array}{l}\text { I will not buy until } \\
\text { promotional activities begin. }\end{array}$ \\
\hline
\end{tabular}

Impulse Buying Behavior

\begin{tabular}{l|l|l} 
Code & Loading & Items \\
\hline
\end{tabular} 


\begin{tabular}{|l|l|l|}
\hline E1 & 0.579 & $\begin{array}{l}\text { I cannot refrain from } \\
\text { purchasing items from online } \\
\text { shops. }\end{array}$ \\
\hline E2 & 0.852 & $\begin{array}{l}\text { Whenever I see attractive } \\
\text { items, I cannot stop myself } \\
\text { from buying products. }\end{array}$ \\
\hline E3 & 0.779 & $\begin{array}{l}\text { If my favorite items are on } \\
\text { sale, I will purchase those } \\
\text { products. }\end{array}$ \\
\hline E4 & 0.733 & $\begin{array}{l}\text { Whenever I see items and } \\
\text { think of the same products at } \\
\text { home are running out. I will } \\
\text { purchase some items to } \\
\text { replace the one used up. }\end{array}$ \\
\hline E5 & 0.619 & $\begin{array}{l}\text { When I see products that I was } \\
\text { unable to afford last time, I } \\
\text { will buy those products this } \\
\text { time. }\end{array}$ \\
\hline
\end{tabular}

[34]suggested that two steps be taken in data analysis for sake of consistency. Thus, the structural model was evaluated for its predictive capability and the hypothesized relationships were tested. The results related to the assessment of the reliability and validity of the constructs are provided in Table 2 , and all indicator item demonstrated a satisfactory level of reliability. According to [6], Cronbach's Alpha and Composite Reliability values of all the constructs should exceed the 0.7. (Please refer to Table 2)

Table 2. Assessment of the Measurement Quality of the Model'S Constructs.

\begin{tabular}{lcccccc}
\hline & $\begin{array}{c}\text { Cronbach } \\
\boldsymbol{\alpha}\end{array}$ & CR & rho_A & AVE & $\mathbf{R}^{\mathbf{2}}$ & $\begin{array}{c}\text { Adj } \\
\mathbf{R}^{\mathbf{2}}\end{array}$ \\
\hline I.B.T & 0.797 & 0.850 & 0.854 & 0.539 & & \\
H.B. & 0.942 & 0.954 & 0.943 & 0.775 & 0.524 & 0.522 \\
W.F. & 0.907 & 0.926 & 0.913 & 0.641 & 0.661 & 0.659 \\
P.T. & 0.93 & 0.947 & 0.931 & 0.781 & 0.679 & 0.677 \\
I.B.B. & 0.771 & 0.840 & 0.837 & 0.517 & 0.388 & 0.387 \\
\hline
\end{tabular}

Composite Reliability (CR), Average Variance Extracted (AVE),rho_A $=$ the most important reliability measure for PLS (Dijkstra \& Henseler, 2015)

I.B.T (Impulse Buying Tendency), H.B. (Herd Behavior), W.F. (Website Features), P.T. (Promotion Techniques), I.B.B. (Impulse Buying Behavior)

The second step, the model was checked for collinearity issues by analyzing the variance inflation factors (VIF). The values of exogenous constructs were measured for the examination of multi-collinearity.

All VIF values of less than 5 indicate the absence of multi-collinearity. We can see the value of the facet questionnaire by following, impulse buying tendency 1.60 2.55, herd behavior 2.49 4.50, website features $2.10 \sim 3.20$, promotion techniques 2.67 4.31 and impulse buying behaviour 1.22 1.71. Afterward, the larger of factor loading (greater than 0.5 ) of each questionnaire, the more convergent it is, as given by Figure 2. The discriminant validity was assessed by referring to Fornell and Larcker's criterion.

Table 2 shows that the square root of the AVE values of all the constructs are higher than their correlation coefficients with other constructs [13].[16]\&[8] both suggested that the AVE of the potential variable should preferably exceed 0.50 . This study has achieved all these requirements.(Please refer to Table 3 )

Table 3. Fornell-Larcker Criterion Analysis for Checking Discriminant Validity

\begin{tabular}{lcccccc}
\hline & I.B.T & H.B. & W.F & P.T. & I.B.B & Met? \\
\hline I.B.T. & 0.734 & & & & & YES \\
H.B. & 0.724 & 0.881 & & & & YES \\
W.F. & 0.670 & 0.802 & 0.801 & & & YES \\
P.M. & 0.688 & 0.802 & 0.726 & 0.884 & & YES \\
I.B.B & 0.533 & 0.533 & 0.520 & 0.623 & 0.719 & YES \\
\hline
\end{tabular}

I.B.T (Impulse Buying Tendency), H.B. (Herd Behavior), W.F. (Website Features), P.T. (Promotion Techniques), I.B.B. (Impulse Buying Behavior)

According to our findings, Cronbach $\alpha$, composite reliability and rho_A all have values higher than 0.70 . Consequently, reliability criteria are met for all items and at the construct level. This study also checked AVE, VIF and correlation coefficients overall indicators. According to the results, this model is acceptable.

This explained that impulsive purchase behavior will affect consumers due to website characteristics, promotion methods, and herd behavior. When a customer sees a certain product or certain advertisements or business promotion at the shopping site, it prompts or arouses the unmet consumer demand of the customer, thereby causing consumer desire, and the decision to buy is the result of stimulation at the shopping site. This result is similarwith [35]mentioned that consumers with high impulsive characteristics are more likely to cause pure impulses. This study proved that impulse buying tendency significant affects herd behavior, website features and promotion techniques. This 
means that $\mathrm{H} 1, \mathrm{H} 2$ and $\mathrm{H} 3$ of this study are acceptable.

This study also demonstrated that herd behavior has a significant effect on website features and promotion techniques. Thus, H4 \& H5 are supported. Herd behavior is blind to varying degrees. It is often that the opinions presented are in line with my own wishes, or that you have no fixed intentions, or that you follow the mainstream thought of "it is not wrong to be with most people". Website features have a significant effect on promotion techniques, showing that $\mathrm{H6}$ is suitable.Website design, website content, website security and privacy have a significant effect on promotion techniques. This is due to consumers cloud safe purchase on the web site.

Finally, this study demonstrated that promotion techniques have a significant effect on impulse buying behavior, proving H7. This shows that smart promotional techniques will make it easier to impress consumers and trigger them to make impulsive purchase. Most hypotheses in this study were shown to have positive effects and the dimensions were connected (see Figure $2 \&$ Table 4), This study shows that all assumptions are true except $\mathrm{H} 8$.

Table 4. Estimates of the Model'S PathCoefficients and their Significance

\begin{tabular}{llcrrr}
\hline & & Beta & Mean & $\begin{array}{c}\text { t- } \\
\text { value }\end{array}$ & \multicolumn{1}{c}{$\begin{array}{c}\text { R2 } \\
(\%)\end{array}$} \\
\hline H1 & I.B.T $\rightarrow$ H.B. & $0.727^{* * *}$ & 0.727 & 33.43 & 52.85 \\
H2 & I.B.T $\rightarrow$ W.F. & $0.190^{* * *}$ & 0.193 & 3.99 & 3.72 \\
\hline H3 & I.B.T $\rightarrow$ P.T. & $0.189^{* * *}$ & 0.193 & 3.73 & 3.76 \\
H4 & H.B. $\rightarrow$ W.F. & $0.663^{* * *}$ & 0.663 & 15.34 & 43.63 \\
H5 & H.B. $\rightarrow$ P.T. & $0.515^{* * *}$ & 0.515 & 9.32 & 26.52 \\
H6 & W.F. $\rightarrow$ P.T. & $0.183^{* *}$ & 0.183 & 3.23 & 3.35 \\
H7 & P.M. $\rightarrow$ I.B.B. & $0.627^{* * *}$ & 0.627 & 18.40 & 39.31 \\
H8 & H.B. $\rightarrow$ I.B.B. & 0.003 & 0.001 & 0.004 & 0.00 \\
H9 & W.F. $\rightarrow$ I.B.B.. & $0.143^{*}$ & 0.144 & 2.06 & 20.5 \\
\hline
\end{tabular}

Bootstrap repeated sampling draws 5,000 samples as parameter estimates;

$* * * \mathrm{p}<.001 * * \mathrm{p}<.01$

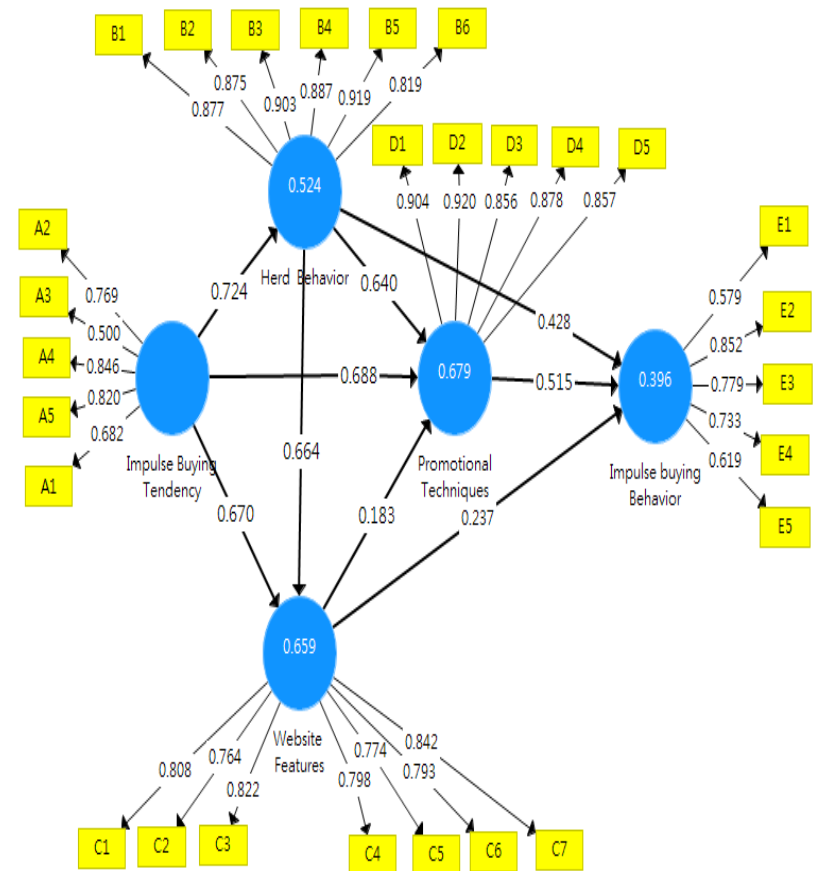

Figure 2. Display of Total Effects of Rresearch Results

Impulse buying tendency has a significant positive impact on herd behaviour $(\beta=.724, \mathrm{t}=33.43, \mathrm{p}<$ .001 ), hence H1 is accepted. The results of the chisquare test of independence for $\mathrm{H} 1$ indicated a statistically significant difference between the observed and expected values, $\chi 2=743.705 \mathrm{df}=$ $480, \mathrm{p}<.000, \mathrm{~N}=364$. The impact of Impulse buying tendency on website features was found significant positive impact $(\beta=.190, \mathrm{t}=3.99, \mathrm{p}<.001)$, hence $\mathrm{H} 2$ was accepted. The results of the chi-square test of independence forH 2 indicated a statistically significant difference between the observed and expected values, $\chi 2=840.096, \mathrm{df}=560, \mathrm{p}<.000$. A significant positive impact of Impulse buying tendency is observed on promotion techniques $(\beta=$ $.189, \mathrm{t}=3.73, \mathrm{p}<.001$ ) due to which $\mathrm{H} 3$ is accepted.The results of the chi-square test of independence for $\mathrm{H} 3$ indicated a statistically significant difference between the observed and expected values, $\chi 2=634.027, \mathrm{df}=400, \mathrm{p}<$ .000 .Herd behaviour has a significant positive impact on website features $(\beta=.663, t=15.34, p<$ .001 ), hence $\mathrm{H} 4$ are accepted.The results of the chisquare test of independence for $\mathrm{H} 4$ indicated a statistically significant difference between the observed and expected values, $\chi 2=1247.752$, $\mathrm{df}=$ $672, p<.000$. The impact of Herd behaviour on promotion techniques was also found significant positive $(\beta=.515, \mathrm{t}=9.32, \mathrm{p}<.001)$, hence $\mathrm{H} 5$ is also accepted.The results of the chi-square test of 
independence for $\mathrm{H} 5$ indicated a statistically significant difference between the observed and expected values, $\chi 2=814.855, \mathrm{df}=480, \mathrm{p}<.000$. The impact of Website features on promotion techniques was found significant positive impact ( $\beta=.183, \mathrm{t}=3.23, \mathrm{p}<.01$ ), hence $\mathrm{H} 6$ was accepted. The results of the chi-square test of independence for $\mathrm{H} 6$ indicated a statistically significant difference between the observed and expected values, $\chi 2=878.530, \mathrm{df}=560, \mathrm{p}<$ .000 .Promotion techniques has a significant positive impact on impulse buying behaviour $(\beta=.327, \mathrm{t}=$ $18.40, \mathrm{p}<.001)$, hence H7 is accepted. The results of the chi-square test of independence for $\mathrm{H} 7$ indicated a statistically significant difference between the observed and expected values, $\chi 2=$ $672.454, \mathrm{df}=400, \mathrm{p}<.000$. Herd behaviour without a significant positive impact on website features $(\beta$ $=.663, \mathrm{t}=15.34, \mathrm{p}=.967$ ), hence $\mathrm{H} 8$ are rejected.The results of the chi-square test of independence for $\mathrm{H} 8$ indicated a statistically significant difference between the observed and expected values, $\chi 2=682.829$, df $=480, \mathrm{p}<$ .000.The significant positive impact of Website feature is observed on impulse buying behaviour $(\beta$ $=.143, \mathrm{t}=2.06, \mathrm{p}<.005)$ due to which hypothesis H9 is accepted. The results of the chi-square test of independence for $\mathrm{H} 3$ indicated a statistically significant difference between the observed and expected values, $\chi 2=760.147$, df $=560, p<$ .000 . By the way, when the SRMR is less than 0.1, it has a good fit. The SRMR of this research model $=.084$ indicating that the research model has a good fit.

\section{Conclusions and suggestions}

The present study used consumers in both China and Taiwan as targets to explore the variables of impulse buying tendency, herd behaviour, website features, promotional techniques, and impulse buying behavior. According to the results, the conclusion and suggestions are presented as follows.

This study shows herd behaviour, website features and promotional techniques are mediating factors between impulse buying tendency and impulse buying behaviour. The literature review showed that awareness of shopping risk is increasing. Due to the fierce competition in the market and the homogenization of products, even for unplanned purchases, consumers still have a huge impact on impulse purchases. The customers nowadays collect more information before they make decisions.

Herd behavior, website features and promotional techniques have significant effects on younger consumers on both sides of the Strait. The findings indicate that under the premise of planned purchases, consumers should consider whether they have the ability according to their budget when buying products. Consumers are constrained by budget shortages or other external factors that limit purchases. Research has also shown that the design and layout of website features are key factors for online businesses. For instance, merchants use colorful advertisements, popular endorsements, bright designs, and exaggerated discount promotions to render a strong shopping festival atmosphere. Cooperating with online shopping restrictions and current promotions successfully mobilizes consumers' shopping hunger. In addition, under the intensive announcement and encouragement of the carnival through various media, the price factor and current emotional conflict make consumers fall into a shopping contradiction, with the resulting consequence that they ignore the future. When customers are facing promotional techniques, when deciding whether to enjoy the moment or to control the impulse and hold back, consumers have more internal conflicts, struggles and imbalances when there is no plan.

In the end, consumers have a significant impact on informational impact and non-price orientation. The research shows that consumers spend more time searching for other consumers' evaluations, which may implicate herd behavior. They not only search for information on products, they also obtain evaluations of these products and information disregarding price. For example, some merchants do not choose to reduce price during promotions, but will offer lot of samples or gifts to attract future consumers. Moreover, personalized services for specific consumer groups are also possible. Regarding web features and promotional techniques, on the other hand, customers are affected by price orientation. The lower price strategy is still a good reason to participate in the shopping festival.

\section{Suggestion}

This study suggest that $(11 / 11)$ is not only a promotional technique, but that consumers have their own cognition and evaluation when shopping online. Thus, website design, the content of the website and the opinions of peers affect consumers' decision making. Finding and providing sufficient, necessary information is the best choice for merchants.

In addition, when making either planned or unplanned purchases at this worldwide promotional shopping festival, consumers are impulsively subject to promotional incentives or added-value 
when exposed to website messages. Therefore, merchants should try to distinguish between high and low impulse characteristics, and use different strategies to propose more attractive promotions for consumers to attract consumers' future purchases.

\section{References:}

[1] Amaro, S., \& Duarte, P., An integrative model of consumers' intentions to purchase travel online, Tourism Management. Vol.46, 2015, pp. 64-79.

[2] Badgaiyan, A. \& Verma, A., Intrinsic factors affecting impulsive buying behaviourEvidence from India, Journal of Retailing and Consumer Services, Vol.21, 2014, PP. 537549.

[3] Bart, Y., V. Shankar, F. Sultan, and G.L. Urban., Sultan, and G.L. Urban. Are the drivers and role of online trust the same for all web sites and consumers? A large-scale exploratory empirical study, Journal of Marketing, Vol.69, No.4, 2005, 133-152.

[4] Boatwright, P., Borle, S., Kadane, B. J., A model of the joint distribution of purchase quantity and timing, Journal of the American Statistical Association, Vol.98, 2003, pp. 564572.

[5] Coulter, K. S. \& Roggeveen, A., Deal or no deal? How number of buyers, purchase limit, and time-to-expiration impact purchase decisions on group buying websites, Journal of Research in Interactive Marketing, Vol.6, No.2, 2012, pp. 78-95.

[6] Dhruv, G., Levy, M. \& Kumar V., Customer Experience Management: An Organizing Framework, Journal of Retailing, Vol.85, No.1, 2009, pp. 1-14.

[7] Dijkstra, T. K., \& Henseler, J., Consistent partial least squares path modeling, MIS quarterly= Management Information Systems Quarterly, Vol.39, No.2, 2015, pp. 297-316.

[8] Dilmperi, A., King, T., \& Dennis, C., Toward a framework for identifying attitudes and intentions to music acquisition from legal and illegal channels, Psychology \& Marketing, Vol.34, No.4, 2017, pp. 428-447.

[9] Fornell, C., \& Larcker, D., Evaluating structural equation models with unobservable variables and measurement error, Journal of Marketing Research, Vol.18, 1981, pp. 39-50.

[10] Fourie, I. \& Ball, L., Promotional strategies for information products and services - aligning with the serious and entertainment facets of information consumers' lives, Library Hi Tech, Vol.30, No.4, 2012, pp. 683-692.
[11] Gangwar, M., Kumar, N. \& Rao, R., Consumer stockpiling and competitive promotional strategies, Marketing Science,Vol.33, No.1, 2014, pp. 94-113.

[12] Guo, L., Villas-Boas, J. M., Consumer stockpiling and price competition in differentiated markets, Journal of Economics and Management Strategy, Vol.16, No.4, 2007, pp. 827-858.

[13] Hair, J. F., Hollingsworth, C. L., International Journal of Science and Technology, International Industrial Management \& Data Systems, Vol.117, No.3, 2017, pp. 442-458.

[14] Hair, J. F., Hult, G. T. M., Ringle, C. M., \& Sarstedt, M., A primer on partial least squares structural equation modeling (PLS-SEM), Thousand Oaks, CA: Sage., 2014.

[15] Hair, J.F., Babin, B.J., Anderson, R.E. and Black, W.C., Multivariate data analysis (8th edition), Cengage India, Delhi, 2018.

[16] Hair, J.F., Ringle, C.M. and Sarstedt, M., PLSSEM indeed a silver bullet, Journal of Marketing Theory and Practice, Vol.19, 2011, pp. 139-151.

[17] Hasan, B., Perceived irritation in online shopping: The impact of website design characteristics, Computers in Human Behavior, Vol.54, 2016, pp. 224-230.

[18] Hing, N., Russell, A. M. T., Li, E., Vitartas, P., Does the uptake of wagering inducements predict impulse betting on sport?, Journal of Behavioral Addictions, Vol.7, 2018, pp. 146157.

[19] Hong, N.T.P. \& LINH, D.T.K., Effects of Earnings Management to Investor Decision Empirical Evidence in Vietnam Stock Market, Wseas Transactions on Environment and Development, Vol. 16, 2020, PP. 84-97.

[20] Ingwersen, P. \& Järvelin, K., The turn: integration of information seeking and retrieval in context, The Netherlands: Springer Netherlands Publisher. J.: Prentice-Hall, Inc., 2005.

[21] Ko, H.C., Exploring the factors driving impulse buying tendency on advertisements of Facebook: a social learning theory perspective, 10th international conference on education technology and computers, 2018, pp. 245-249.

[22] Koch, A, Herd behavior and mutual fund performance, Management Science, Vol.63, No.11, 2017 pp. 3849-3873.

[23] Koufaris M., Applying the technology acceptance model and flow theory to online consumer behavior, Information Systems Research, Vol.13, No.2, 2002, pp. 205-223. 
[24] Kremer, S. \& Nautz, D., Causes and consequences of short-term institutional herding, Journal of Banking \& Finance, Vol.37, No.5, 2013, pp. 1676-1686.

[25] Li, C.Y., THow social commerce constructs influence customers' social shopping intention? An empirical study of a social commerce website, Technological forecasting and social change, Vol.144, 2019, pp. 282-294.

[26] Lin, P.C., \& Lin, Z. H.,Buying impulse triggered by digital media, Service Industries Journal, Vol.33, No.9-10, 2016, pp. 892-908.

[27] Liu, Q. \& Zhang, F, Study on the Influencing Factors of Mobile Users' Impulse Purchase Behavior in a Large Online Promotion Activity, Journal of Electronic Commerce in Organizations, Vol.17, No.2, 2019, pp. 88-101.

[28] Liu, Y.\& Sutanto, J., Buyers' purchasing time and herd behavior on deal-of-the-day groupbuying websites, Electronic Markets, vol. 22, no. 2, 2012, pp.83-93

[29] Mallapragada, G., Chandukala, S. R., \& Liu, Q., Exploring the effects of "What" (Product) and "Where" (Website) characteristics on online shopping behavior, Journal of Marketing, Vol.80, No.2, 2016, pp. 21-38.

[30] Quelch, J. A., Sales Promotion Management, Englewood Cliffs, N. J., Prentice-Hall, Inc., 1989.

[31] Racherla, P., \& Friske, W., Perceived usefulness of online consumer reviews: An exploratory investigation across three services categories, Electronic Commerce Research and Applications, Vol.11, No.6, 2012, pp. 548-559.

[32] Robbins, S. S., \& Stylianou, A. C., Global corporate web sites: an empirical investigation of content and design, Information \& Management, Vol.40, No.3, 2003, pp. 205-212.

[33] Rook, Dennis W., \& Fisher, Robert J., Normative influences on impulsive buying behavior, Journal of Consumer Research, Vol.22, 1995, pp. 305-313.

[34] Sarstedt, M., Ringle, C. M., Smith, D., Reams, R., \& Hair, J. F., Partial Least Squares Structural Equation Modeling (PLS-SEM): A Useful Tool for Family Business Researchers, Journal of Family Business Strategy, Vol.5, No.1, 2014, pp. 105-115.

[35] Shahjehan, A. and Qureshi, J.A, Personality and impulsive buying behaviors, A necessary condition analysis, Economic ResearchEkonomska Istraživanja, Vol.32, No.1, 2019, pp. 1060-1072.
[36] Shimp, T. A., Promotion management and marketing communications, Chicago, IL: Dryden Press, 1993.

[37] Stern, H., The significance of impulse buying today, Journal of Marketing, Vol.26, No.2, 1962, pp. 59-62.

[38] C.N.A., T-mall sets a new record for double 11 in 2019 with more than 1.15 trillion Taiwan dollars (September 12), Central News Agency (C.N.A.), 2019.

[39] Verhagen, T., \& van Dolen, W., The influence of online store beliefs on consumer online impulse buying: A model and empirical application, Information \& Management, Vol.48, 2011, pp. 320-327.

[40] Wu, I.-L. \& Chen, K.W. \& Chiu, M. L., Defining key drivers of online impulse purchasing: A perspective of both impulse shoppers and system users, International Journal of Information Management, Vol.36, No.3, 2016, pp. 284-296.

[41] Xiang, L., Zheng, X., Lee, M. K. O., and Zhao, D., Exploring consumers' impulse buying behavior on social commerce platform: the role of parasocial interaction, International Journal of Information Management, Vol.36, No.3, 2016, pp. 333-347.

[42] Xin, Shengmin \& Zheng, Mutual fund herding and stock price crashes, Journal of Banking \& Finance, Vol.94, 2018, pp. 166-184.

[43] Yen, C. and Chang, C.M, ying behavior in Taiwan from a collectivism perspective. Journal of Electronic Commerce Research. 2015, Journal of Electronic Commerce Research, Vol.16, No.2, 2015, pp. 109-122.

[44] Youn, S. \& Faber, R., Impulse buying: Its relation to personality traits and cues, Advances in Consumer Research, Vol.27, No.1, 2000, pp. 179-185.

[45] Zhu, F. \& Zhang, Z., Impacts of online consumer reviews on sales: The moderating role of product and consumer characteristics, Journal of Market, Vol.74, 2010, pp. 133-148.

[46] Zia, M. \& Rao, R. Search advertising: budget allocation across search engines, Marketing Science, Vol.38, No.6, 2019, pp. 1023-1037.

Creative Commons Attribution License 4.0 (Attribution 4.0 International, CC BY 4.0) This article is published under the terms of the Creative Commons Attribution License 4.0 https://creativecommons.org/licenses/by/4.0/d eed.en_US 